\title{
Chemical and ecotoxicological analyses to assess the environmental risk of the Garigliano River (central Italy)
}

\author{
N. Calace ${ }^{1}$, B. M. Petronio ${ }^{1}$, M. Pietroletti ${ }^{1}$, E. Palmaccio $^{1}$, \\ T. Campisi ${ }^{2} \&$ A. Iacondini ${ }^{2}$ \\ ${ }^{1}$ Department of Chemistry, University "La Sapienza”, Italy \\ ${ }^{2}$ Centro Ricerche e Servizi Ambientali Fenice S.p.A., Italy
}

\begin{abstract}
The aim of this paper was to assess the environmental risk of the Garigliano River on the Tyrrenean Sea. In particular we focused our attention on the chemical and ecotoxicological quality of the river. Nine stations (sediment) were analysed along the last $10 \mathrm{~km}$ before the sea for heavy metal content. Moreover, three ecotoxicological tests (Vibrio fischeri with Microtox ${ }^{\circledR}$, Pseudomonas fluorescens DHase inhibition assay, Pseudokirchneriella subcapitata inhibition test) were carried out on sediment samples in order to evaluate the toxicity of the matrices. The principal components analysis (PCA) and clustering were performed in order to correlate all the data. The results showed that heavy metal content $(\mathrm{Cu}, \mathrm{Pb}, \mathrm{Ni}, \mathrm{Cd}, \mathrm{Zn}, \mathrm{Fe}$ and $\mathrm{Mn})$ is low in all stations; these data reflected the results obtained from ecotoxicological tests that showed no toxic matrices, except for one station. An integrated chemical and ecotoxicological approach applied on the Garigliano River found that actually its environmental impact is not hazardous for the Tyrrenean Sea.

Keywords: Vibrio fischeri test, Pseudomonas fluorescens test, algal test, heavy metals, Pseudokirchneriella subcapitata.
\end{abstract}

\section{Introduction}

In recent years, the assessment of the effect of sediment pollution on indigenous microflora has received more attention and an ecological interest [1]. Concentrations of contaminants in the environment are primarily determined by 
analytical chemical measurements, but often they do not provide direct information regarding biological effects of toxic compounds nor about the concentration available for microbial biodegradation [2]. The increasing in international regulations and the assessment of the potential risk caused by sediment pollution have focused on the need for rapid, reliable and accurate assays for soil and sediment environment. Using bioassays, the presence of toxic compounds and their biological and ecological risks can be determined. Moreover, among all the developed toxicity tests, bioassays with exogenous microorganisms or enzymes may be used to give information on the bioavailability and toxicity of the pollutants in soil and sediment $[3,4,5]$.

Generally, regulations assume that acceptable concentrations for pollutants can be treated independently, even they are present in mixtures, but in many cases these assumptions may be uncorrected. Indeed, hazardous wastes sites often contain complex mixtures of pollutants which include both organic contaminants and heavy metals [6]. In particular, additive, synergistic or antagonistic interactions can take place when a target organism is exposed to mixtures of pollutants. Toxicity assessment of multiple combinations of different pollutants requires application of sensitive, rapid and reliable bioassays [7]. Among them, Pseudomonas fluorescens was successfully used in a new bioassay [8] to assess the ecotoxicity of heavy metals in soils [9]. Moreover, in order to obtain an ecological evaluation, two traditional bioassays were coupled to the new one: a test with the bioluminescent bacterium Vibrio fischeri (Microtox ${ }^{\circledR}$ ) and an algal test with Pseudokirchneriella subcapitata. The aim of this work was to assess the environmental risk of the Garigliano River (Italy) on the Tyrrenean Sea. This study was carried out by means chemical analyses and ecotoxicological tests, in order to find also correlations between the two data.

\section{Materials and methods}

\subsection{Samples collection}

Sediments $(0-10 \mathrm{~cm})$ were collected in June 2004 with a van Veen grab sampler. The stations were sampled by the delta (station 1) of the river toward the hinterland to a distance of $1 \mathrm{~km}$ each other (overall 9 stations).

Sediments were immediately stored in polyethylene bags and frozen at $-20^{\circ} \mathrm{C}$. Before the analyses, the samples were lyophilised and homogenised.

\subsection{Chemical analyses}

\subsubsection{Metal determination}

Aliquots of sediment $(0.20 \pm 0.01 \mathrm{~g})$ were introduced into PTFE vessels and $8 \mathrm{ml}$ of concentrated $\mathrm{HNO}_{3}, 4 \mathrm{ml}$ of $48 \% \mathrm{HF}$ and $2 \mathrm{ml}$ of concentrated $\mathrm{H}_{2} \mathrm{O}_{2}$ were added into vessels. The acid mixture was optimised in order to destroy completely the solid matrix. Then closed vessels with valve were introduced into a microwave oven working under the following conditions: $250 \mathrm{~W}, 5 \mathrm{~min} ; 400$ W, $5 \mathrm{~min} ; 600 \mathrm{~W}, 10 \mathrm{~min}$. Iron, copper, lead, manganese, zinc, nickel and 
cadmium concentrations were determined by a Varian SpectrAA-10 atomic absorption spectrometer working with an air-acetylene flame.

The procedure was tested using two reference materials: IAEA-356 Polluted Marine Sediment and MURST-ISS-A1 Antarctic Marine sediment.

\subsubsection{Total organic carbon determination}

Total organic carbon was determined by means of elemental analysis on sediment previously acidified with concentrated $\mathrm{HCl}$ to eliminate carbonates. Briefly, $100 \mathrm{mg}$ of sediment was weighed out, acidified with $500 \mu \mathrm{l} \mathrm{of} \mathrm{HCl}$ and then dried under an infrared lamp. The residue was again weighed and analysed using a Carlo Erba model EA11110 CHNS-O Element Analyser. The percentage carbon obtained from elemental analysis was recalculated for the original sediment and expressed as $\mathrm{mg} / \mathrm{g}$. The limit of detection (LOD) was $0.3 \%$.

\subsection{Toxicity tests}

\subsubsection{Vibrio fischeri test}

The Microtox ${ }^{\circledR}$ Basic Solid Phase Test (BSPT) was performed according to standard operating procedure $[10,11]$ and the end point is the inhibition of light emission by the marine bacterium $V$. fischeri. Briefly, seven grams $( \pm 0.01 \mathrm{~g})$ of sediment were tested as suspensions prepared with $35 \mathrm{ml}$ of diluent $(35 \mathrm{~g} / \mathrm{l} \mathrm{NaCl}$ solution) and diluted to a series of 9 concentrations, in the incubator wells (Microtox ${ }^{\circledR}$ model 500 Analyser). Light readings were recorded at 5, 15, and 30 minutes, and, in this work, measures at $30 \mathrm{~min}$ were reported. Regression statistics of concentration $(\log C)$ on the gamma parameter $(\log \Gamma)$ were used to estimate the correlation which gives a nominal toxic effect. The software supplied by Azur Environmental calculated the EC50 value (g/l), and Toxicity Unit (TU, as 100/EC50). The greater the TU value, the greater the toxicity.

\subsubsection{Pseudomonas fluorescens DHase inhibition assay}

As screening test, DHase inhibition assay has been performed according to Guerra et al. [8] and Abbondanzi et al. [9]. The bacterium P. fluorescens ATCC 13525 was used after inoculum standardisation, at a concentration of 4-5 x $10^{6}$ CFU ml $\mathrm{ml}^{-1}$. The activity of dehydrogenase enzymes is linked to the respiratory and energy producing processes in the cell, and basically depends on the metabolic state of microrganisms. The dehydrogenase activity measures were carried out using 2,3,5-triphenyl tetrazolium chloride (TTC) as artificial electron acceptor. This salt is reduced by microbial activity to red coloured formazan, that can be determined with spectrophotometric measures (wavelength: $482 \mathrm{~nm}$ ). After a 48 -h incubation in the dark at $30^{\circ} \mathrm{C}$, TPF was extracted with acetone for $2 \mathrm{~h}$ and its concentration was then determined spectrophotometrically. The test was conducted on total sediment matrix.

A garden soil was used as control soil, after chemical and chemical physical characterisations ( $80 \%$ sand, $20 \%$ silt and clay, $6.7 \%$ organic matter contents). The screening test was performed for every sediment sample, in order to estimate the Inhibition (I), calculated from TPF concentrations in samples and control: 


$$
\% I=\frac{\left(T P F_{\text {control }}-T P F_{\text {sample }}\right)}{T P F_{\text {control }}} 100
$$

where TPFcontrol is the average of TPF concentration in control and TPFsample is the TPF average in sample (four replicates).

\subsubsection{Pseudokirchneriella subcapitata inhibition test}

Pseudokirchneriella subcapitata inhibition was performed as screening test and the green alga $P$. subcapitata (formerly known as Selenastrum capricornutum) was used following standard algal assay procedure [12, 13]. Cell growth inhibition was used as the endpoint in the toxicity experiments. Briefly, five grams $( \pm 0.01 \mathrm{~g})$ of sediment were suspended in $20 \mathrm{ml}$ of algal culture (AAP) medium, without EDTA [13]. After $1 \mathrm{~h}$ of shaking, the suspension was centrifuged at a $3200 \mathrm{rpm}$ for $20 \mathrm{~min}$ and the surnatant was tested. The $P$. subcapitata culture was harvested at a cell density of $10^{6} \mathrm{cells} / \mathrm{ml}$, inoculated in surnatant and then incubated at $20 \pm 1^{\circ} \mathrm{C}$ under 5000-6000 Lux light. After 72-h incubation, the cell growths were estimated by manual counting method in samples and in control (ultrapure water), in order to calculated cell growth inhibition (I\%), as for P. fluorescens DHase inhibition test.

\section{Statistical analysis}

The principal component (PCA) and clustering analyses were performed from Statgraphics plus 5.1 demo. PCA is a multivariate data reduction method that examines the variance patterns within a multidimensional dataset. The dimensionality of the dataset is reduced while retaining a major portion of the original information. This is accomplished by decomposing the correlation matrix of the variables of the data into a new set of axes, principal components, which define the directions of the major variances in the dataset. The principal components are linear combinations of the variables, comprised of three matrices that define the principal component: scores, loadings, and residuals. These matrices facilitate visualization of the relationships of the samples in the dataset and interpretation of the data. Clustering analysis supplies information about similarities between different variables. It was carried out by means of Ward's method with square Euclidean distance.

\section{Results and discussion}

Figure 1 shows the results of the two screening tests, using Pseudomonas fluorescens on sediment matrix and Pseudokirchneriella subcapitata on surnatant. For $P$. fluorescens DHase inhibition assay, the toxic effect was detected only in station $4(21,8 \%)$, while for the other sampling points, the effect on test organism resulted as a no toxicity (inhibition in station 3 was $<10 \%$, corresponding to a no toxic effect) or, mostly, a stimulation. The effect trend of $P$. subcapitata was mostly in according with $P$. fluorescens, except for station 1 and 2, and for station 3 which produced a stimulation effect in the algal test. In 
station 1 and 2, which are near the mouth of the river, the salinity was high (7 and $0.44 \%$ in station 1 and 2 respectively, against $0.10 \%$ in the other stations) and probably caused an adverse effect on test organism, which is a freshwater alga. The station 4 produced the higher inhibition on both test organisms $(21,8 \%$ and $28.8 \%$ for bacteria $P$. fluorescens and alga $P$. subcapitata, respectively) and showed the higher toxic effect also with BSPT, using the marine bacteria $V$. fischeri, as shown in Figure 2 and in Table 1 (rank 1). In Table 1, a comparison between all the ecotoxicological tests was presented, using ranking method (1 stands for the highest effect, and 9 stands for the lowest effect). The order of sensitivity was bacterium $V$. fischeri $>$ bacterium $P$. fluorescens $>$ alga $P$. subcapitata. Moreover, a good agreement was found for station 4 that obtained the rank 1 for all the tests.

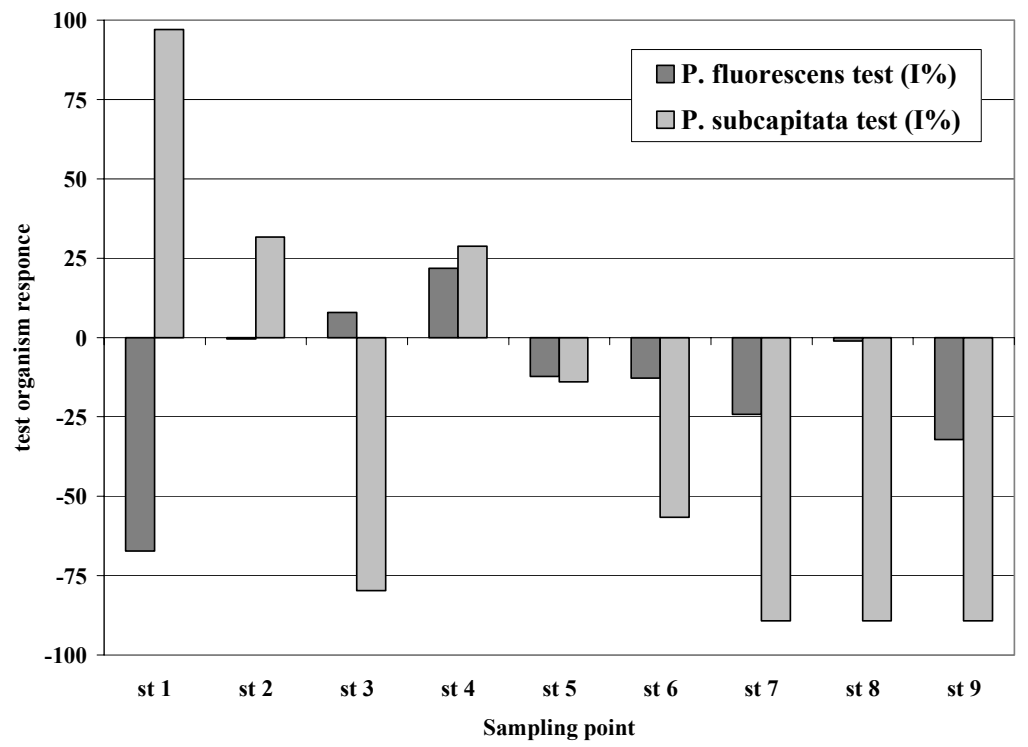

Figure 1: Results of two screening tests.

The findings found by means of ecotoxicological tests could be related to the total organic carbon content and to the zinc, nickel and copper amount of the sediments (Table 2). Station 4 was indeed characterised by the highest organic carbon, zinc, copper and nickel amount probably due to anthropogenic input.

Principal Component Analysis (PCA) was applied to analyse the correlation matrix obtained from a $(8 \times 9)$ data matrix. The 8 variables were TOC, Ni, $\mathrm{Cu}$, $\mathrm{Cd}, \mathrm{Zn}, \mathrm{Fe}, \mathrm{Mn}$ and $\mathrm{Pb}$. In the space of "eigenvectors", the dimensions were reduced to 2 principal axes, which account for about $82 \%$ of the total variance. The Varimax-rotated matrix obtained by the principal components showed that TOC, $\mathrm{Cu}, \mathrm{Zn}$, and $\mathrm{Ni}$ were bonded to the first principal component, while Fe, Mn and $\mathrm{Pb}$ to the second (Figure 3). Moreover stations 2, 3, 4 and 5 were described by the first principal component. 


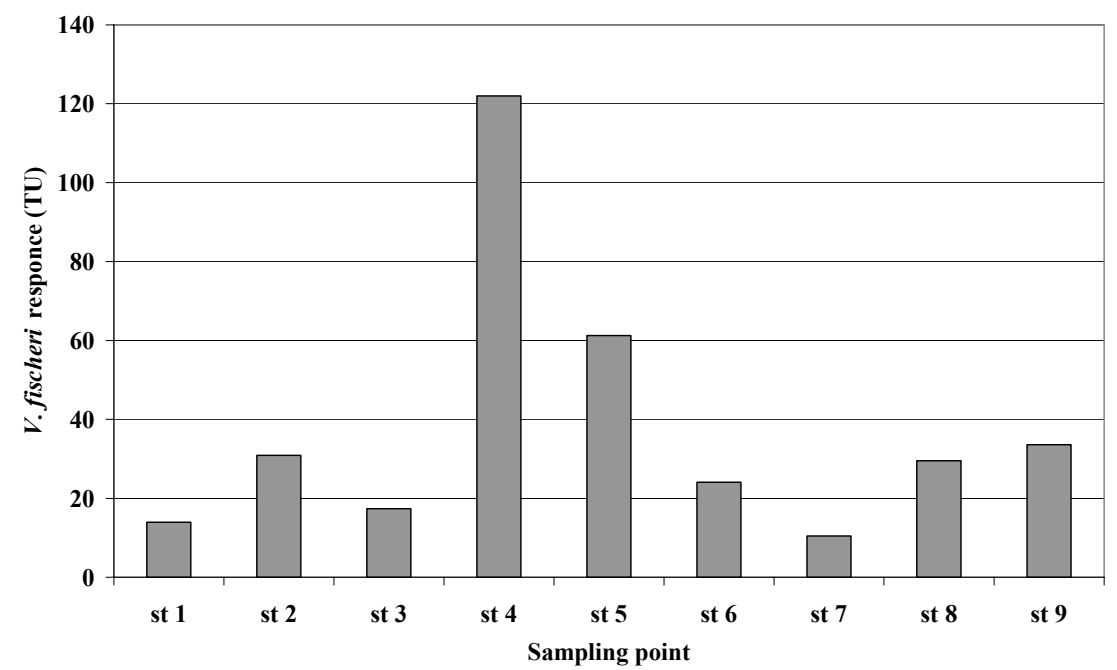

Figure 2: Toxicity Unit results for the nine sampling points on Garigliano River.

Table 1: Comparison of ranking of the three ecotoxicological tests, excluding the station 1 and 2 for P. subcapitata test. Rank 1: the highest effect; rank 9: the lowest effect.

\begin{tabular}{|c|c|c|c|}
\hline $\begin{array}{c}\text { Sampling } \\
\text { points }\end{array}$ & $\begin{array}{c}\text { V. fischeri test - } \\
\text { ranking }\end{array}$ & $\begin{array}{c}\text { P. fluorescens test } \\
\text { - ranking }\end{array}$ & $\begin{array}{c}\text { P. subcapitata test } \\
\text { - ranking }\end{array}$ \\
\hline st 1 & 8 & 9 & $/$ \\
\hline st 2 & 4 & 3 & 4 \\
\hline st 3 & 7 & 2 & 1 \\
\hline st 4 & 1 & 1 & 2 \\
\hline st 5 & 2 & 5 & 3 \\
\hline st 6 & 6 & 6 & 5 \\
\hline st 7 & 9 & 7 & 6 \\
\hline st 8 & 5 & 4 & 7 \\
\hline st 9 & 3 & 8 & \\
\hline
\end{tabular}

This finding should be explained, by considering the associations of the chemical variables from different sources. The first principal component was attributable to an anthropogenic source while the second one to lithological source. On the other hand, this attribution was supported by taking into account that the Ausenta River, which is interested by several agricultural and urban activities on its riverbanks, flows into Garigliano River in front of the station 4. A clustering analysis of ecotoxicological and chemical data was carried out by 
means of Ward's method with squared Euclidean distance, highlighted three clusters having similarities (Figure 4).

Table 2: Results of chemical characterisation (Total Organic Carbon content as $\mathrm{mg} / \mathrm{g}$, and total metal content as $\mathrm{mg} / \mathrm{kg}$ of the sediments).

\begin{tabular}{|c|c|c|c|c|c|c|c|c|}
\hline $\begin{array}{c}\text { Sampling } \\
\text { points }\end{array}$ & TOC(*) & $\mathbf{Z n}(* *)$ & $\mathbf{M n}(* *)$ & $\mathbf{N i}(* *)$ & $\mathbf{P b}(* *)$ & $\mathbf{C d}(* *)$ & $\mathbf{F e}(* *)$ & $\mathbf{C u}(* *)$ \\
\hline st 1 & 3,0 & 38,7 & 474,9 & 23,0 & 57,7 & 6,2 & 5687 & 5,0 \\
\hline st 2 & 16,0 & 90,4 & 519,6 & 38,1 & 59,8 & 2,4 & 5738 & 34,8 \\
\hline st 3 & 16,1 & 89,8 & 482,5 & 32,0 & 72,4 & 3,0 & 7565 & 40,2 \\
\hline st 4 & 16,8 & 107,2 & 430,1 & 39,6 & 60,9 & 2,7 & 8621 & 46,5 \\
\hline st 5 & 14,4 & 73,7 & 471,3 & 28,1 & 57,8 & 2,5 & 5310 & 21,6 \\
\hline st 6 & 12,1 & 71,9 & 583,6 & 31,3 & 62,4 & 2,7 & 14072 & 16,5 \\
\hline st 7 & 9,8 & 63,0 & 449,9 & 29,5 & 59,9 & 1,9 & 6723 & 19,9 \\
\hline st 8 & 2,1 & 61,2 & 679,8 & 18,6 & 90,6 & 1,9 & 15686 & 13,0 \\
\hline st 9 & 10,1 & 64,9 & 477,9 & 19,1 & 78,4 & 2,1 & 6092 & 19,9 \\
\hline
\end{tabular}

(*) Relative standards deviation is less than $5 \%$ (five replicates).

(**) Relative standards deviation is less than $3 \%$ (six replicates).

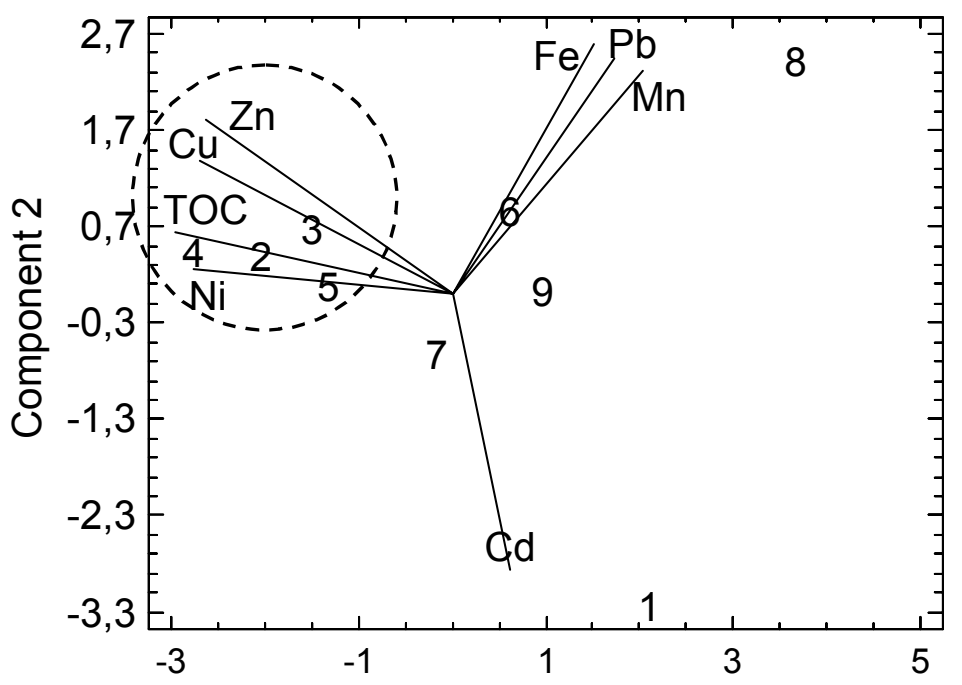

Component 1

Figure 3: $\quad$ Principal component analysis (PCA). 


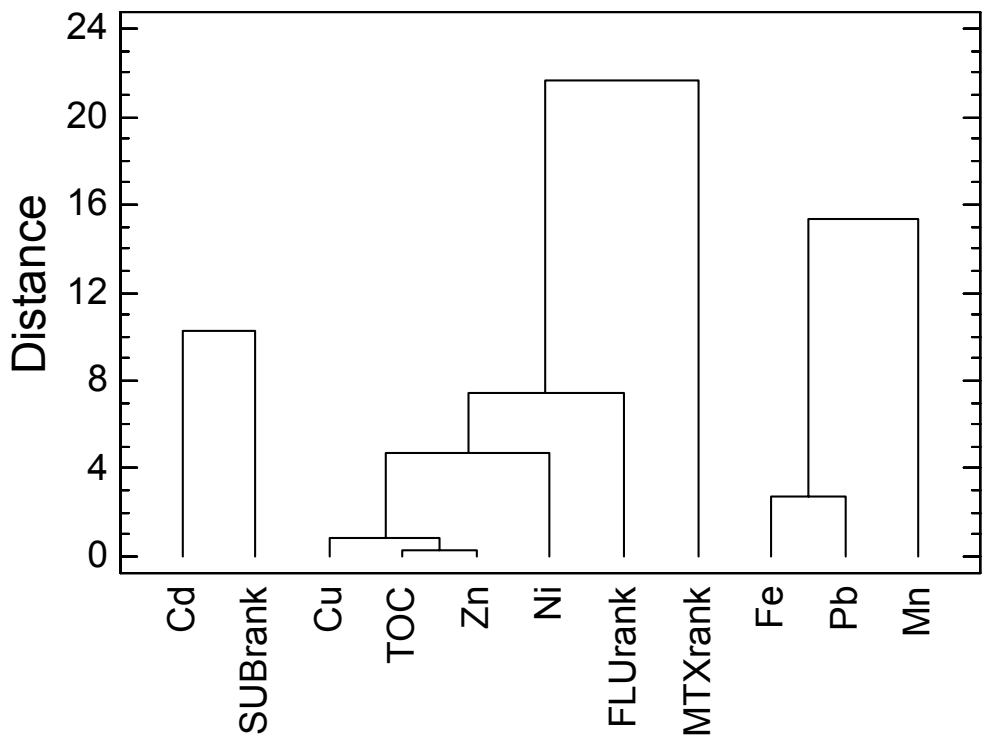

Figure 4: Clustering analysis (Ward's method and squared Euclidean distance). SUBrank, FLUrank and MTXrank stand for $P$. subcapitata test, $P$. fluorescens test and $V$. fischeri test, respectively.

One cluster of them represents the $V$. fischeri (MTXrank) and P. fluorescens (FLUrank) test data and TOC, $\mathrm{Zn}, \mathrm{Cu}$ and $\mathrm{Ni}$ concentration highlighting the correlation between the toxic effect and the chemical data due to anthropogenic input.

$V$. fischeri sensitivity to heavy metals was well know and demonstrated in different studies [14, 15]. Considering Pseudomonas fluorescens DHase inhibition assay, the bacterium showed a good response in heavy metals soil and sediment bioassay, resulting more sensitive to heavy metals than to organic compounds toxicity effects, both singularly and in complex matrices [16]. Regarding Pseudokirchneriella subcapitata inhibition test, toxicity of heavy metals (i. e. Cd and $\mathrm{Zn}$ ) to the green alga was demonstrated [17], confirming the clustering result for $\mathrm{Cd}$.

\section{Conclusion}

An assessment of the environmental risk of the Garigliano River (Italy) was conducted on nine stations, sampled $9 \mathrm{Km}$ back into the river from the delta. Only one stations (station 4) showed a significant toxicity effect to Vibrio fischeri, Pseudomonas fluorescens and Pseudokirchneriella subcapitata demonstrating a specific-spot contamination. Thus, integrated chemical and 
ecotoxicological approach applied on Garigliano River pointed out that actually its environmental impact is not hazardous for Tyrrenean Sea.

\section{References}

[1] Carbonell, G., Pablos, M. V., Garcia, P., Ramos, C., Sanchez, P., Fernandez, C. \& Tarazona, J. V. Rapid and cost-effective multiparameter toxicity tests for soil microorganisms. The science of the total environment, 247, pp. 143-150, 2000.

[2] Power, M., van der Meer, J. R., Tchelet, R., Egli, T. \& Eggen, R.. Molecular-based method can contribute to assessments of toxicological risks and bioremediation strategies. Journal of Microbiological Methods, 32, pp. 107-119, 1998.

[3] Brohon, B., Delolme, C. \& Gourdon, R. Complementarily of bioassays and microbial activity measurements for the evaluation of hydrocarboncontaminated soil quality. Soil Biology \& Biochemistry, 33, pp. 883-891, 2001.

[4] Torslov, J. Comparison of bacterial toxicity tests based on growth, dehydrogenase activity and esterase activity of Pseudomonas fluorescens. Ecotoxicology and Environmental Safety. 25, pp. 33-40, 1993.

[5] Meikle, A., Amin-Hanjani, S., Glover, L. A., Killham, K., \& Prosser, J. I. Matrix potential and the survival and activity of a Pseudomonas fluorescens inoculum in soil. Soil Biology \& Biochemistry, 27 (7), pp. 881-892, 1995.

[6] A, Konopka, T. Zakharova, M. Bishoff, L. Olivier, C. Nakatsu \& R.F. Turco. Microbial biomass and activity in lead-contaminated soil. Applied and Environmental Microbiology, 65 (5), pp. 2256-2259, 1999.

[7] S. Preston, N. Coad, J. Townend, K. Killham, \& G.I. Paton.. Biosensing the acute toxicity of metal interactions: are they additive, sinergistic, or antagonistic? Environmental Toxicology and Chemistry, 19 (3), pp. 775 $780,2000$.

[8] Guerra, R., Iacondini, A., Abbondanzi, F., Matteucci, C., \& Bruzzi, L. A new microbial assay for the toxicity detection of contaminated soils. Annali di Chimica. Annali di Chimica, 92, pp. 847-854, 2002.

[9] F. Abbondanzi, A. Cachada, T. Campisi, R. Guerra, M. Raccagni, \& A. Iacondini. Optimisation of a microbial bioassay for contaminated soil monitoring: bacterial inoculum standardisation and comparison with Microtox ${ }^{\circledR}$ assay, Chemosphere, 53 (8), pp. 889-897, 2003.

[10] Azur Environmental. 1995. Microtox ${ }^{\circledR}$ Acute toxicity Basic Solid Phase Test. Microtox ${ }^{\circledR}$ Acute toxicity Basic Test procedures. Carlsbad, CA, USA.

[11] Campisi, T., Abbondanzi, F., Casado-Martinez, C., DelValls, T.A., Guerra, R. \& A. Iacondini. Effect of sediment turbidity and color on light output measurement for Microtox ${ }^{\circledR}$ basic solid-phase test. Chemosphere, 60(1), pp. 1715-1721, 2005. 
[12] USEPA, 1994. Short term methods for estimating the chronic toxicity of effluents and receiving waters to freshwater organisms. EPA/600/491/002 3rd edition - US Environmental Protection Agency, Cincinnati, Ohio.

[13] Sbrilli G, Calamati E, Boccalini S, Bimbi B, \& Pistolesi F. Effects of nutrients and salinity on the algal assay using Pseudokirchneriella subcapitata (Korshikov) Hindak. Bull Environ Contam Toxicol. 71(3), pp. 609-616, 2003.

[14] Stronkhorst, J., Schipper, C., Brils, J., Dubbeldam, M., Postman, J., \& Van De Hoeven, N. Using Marine Bioassays to Classify the Toxicity of Dutch Harbor Sediments. Environmental Toxicology and Chemistry. 22, pp. 1535-1547, 2003.

[15] Allen Burton Jr., G., Baudo, R., Beltrami, M., \& C. Rowland. Assessing sediment contamination using six toxicity assays. Journal of Limnology. 60(2), pp. 263-267. 2001.

[16] Abbondanzi, F., Cachada, A., Campisi, T., Castro Ruiz, A., Guerra, R., Raccagni, M., \& A. Iacondini. Use of Pseudomonas fluorescens in a contaminated soil bioassay. Proc. of the 8th International FZK / TNO Conference on Contaminated Soil. CD version, 2003.

[17] Koukal, B., Guéguen, C., Pardos, M., \& Dominik, J. Influence of humic substances on the toxic effect of Cadmium and Zinc to the green alga Pseudokirchneriella subcapitata. Chemosphere, 53, pp. 953- 961, 2003. 